\title{
Disha: Building Bridges-Removing Barriers: Where Excluded and Privileged Young Adults Meet
}

\author{
Sadhana Natu
}

\subsection{Introduction}

'Disha' which means Direction is a Speak Out and Peer Support Group started in 1992 in a Pune City College in India for students, which I facilitate. Against the backdrop of globalization in India in 1991, I thought that such a group was the need of the hour. It is a gender-just, non-discriminating, humane platform that allows dialogue, debate and dissent. It also creates a space for friendships, bonding and nurture. The commonalities and differences help to embrace 'multiple realities' which in turn help to look at life, issues and conflicts in a new light [1]. The group is managed by student coordinators and those who participate range from urban poor to those who come from various states in India and various countries. There are first- and second-generation learners as well as well-to-do students, the group is truly inclusive. This aspect is both a challenge and the strength of the group. The Model that we follow is Peer Support, Peer Learning, Feminist Counselling and Empathetic Listening. What works is that they can validate, challenge as well as view their experiences against the backdrop multiple realities and gain a sense of proportion [2].

I am describing these vignettes which are outcomes of discussions on a couple of topics that are areas of concern for the students in order to narrate the effectiveness of listening to and learning from diversities, which is the catalyst for change in the Speak Out and Peer Support Group. The sheer multiplicity of voices enables the

\footnotetext{
S. Natu $(\square)$

Department of Psychology, Modern College, Ganeshkhind, Savitribai Phule Pune University, Pune, India
}

Women's Studies, Pune University, Pune, India

Psychology, Pune University, Pune, India

National and international Journals of Psychology, Pune University, Pune, India

Disha Peer Support and Speak Out Group, Pune University, Pune, India 
students to hole their own singular experience under a lens. I have chosen two topics that bring out this diversity and multiplicity beautifully.

\subsection{Vignettes of the Discussion on Loneliness in Disha}

The students who hailed from rural areas and poorer backgrounds confessed that they felt isolated and alienated from both their surroundings and classmates due to the cultural differences and lifestyle in the city. They were trying their best to adjust and assimilate and wanted to feel that they 'belonged'. The middle and upper middle-class students spoke more about personal loneliness, feeling disconnected, cut off, alone if their friends or families did not listen or respond to them, as against the social loneliness of their other classmates. The students from other states and countries spoke about a deep sense of 'being an outsider' who had difficulties with local language, culture, practices and hence felt bereft at times. The solutions that were put forth were that they should try to speak out as they had done in the group, ask for help and the local students should take the initiative in reaching out to those who were new to both the city and life away from homes. The discussion foregrounded the existence of multiple realities and contexts and underscored the need to build bridges in order to bond across this sea of contrasts.

\subsection{Vignettes of the Discussion on Meanings of Freedom in Disha}

A student hailing from a rural area said that studying in a College in a city gave her the freedom to dress in a way of her choice, talk to boys, take in the sights in the city and enjoy the entertainment that the city had to offer. She also had the freedom to pursue her academic dreams. All of this was non-existent while she was studying in a school and junior college in her village. Another student from a neighbouring state expressed that staying 'away from home' he could avail of a lot of freedoms! Take decisions about food and clothes choices, choose friends, entertainment, hobbies. He was monitored constantly by his parents through calls on the cell phone; nevertheless, he was happy with his 'limited freedoms'. The discussion also included their views about gender differences in rationing out freedom. The restrictions, demands and accountability were more applicable to the female students. The male students had more freedom compared to the females. One student felt that Disha was a 'safe place', and she felt truly free in this group. Free enough to talk about her sexuality. She said that she was gender fluid and called herself queer. She had no support from her parents and family, but with her peers in Disha who discussed their concerns so openly, she wanted to share this part of her life. Another girl spoke about the caste discrimination she faced, both subtle and direct. She said that all freedoms come with responsibilities, the constitutional responsibility to treat your fellow beings as equals! The group responded with maturity and solidarity towards 
all the issues raised vis-a-vis freedom: caste, sexuality, gender, rural-urban divide and more. The wonderful part of the discussion was that the coordinators, while summing up, exhorted the group to analyse and understand the differences and similarities amongst each other as young adults and not homogenize the group. This artificial homogenization takes away the inherent inequalities that existed within the group. A good way ahead was to acknowledge them, accept them and to work actively towards removing discrimination and bigotry and try to achieve true psychological freedom and security for individuals and groups. The fact that this discussion took place on 14 August, the eve of Indian Independence Day made it more meaningful and poignant. The session ended with a chorus recital of Gurudev Rabindranath Tagore's epic poem 'Where the Mind is without Fear' from the Geetanjali.

\subsection{Alumnus Disha Coordinator Profile}

\section{I am a Role Model too!}

For the rest of the college, I did not exist. Why? I am dark, I come from a poor background, do not wear fancy clothes and I am certainly not attractive! It does not amount to much that I topped the college every year, am sincere, kind-hearted. That does not matter. You must have 'attitude' and you must impress, and you must be able to speak English. The only place where what I said mattered, where I mattered was Disha! It is a platform for the intellect, the mind and emotions. Nobody judges you. Your background does not matter. In fact, after I did my Master's in Social Work overcoming all odds, I have been invited several times to interact with the present members and hailed as a role model of sorts!

When I embarked on an MSW course I had a tough time emotionally, mentally and financially. I was really depressed. But thank God, I could not afford the fees of a professional- I survived! My friends from Disha and my MSW course and my mentor helped to come to grips with the situation and to deal with my problems. This journey has made me stronger and happier than I ever was. I share my story with a younger group in Disha every year [1].

\subsection{Disha Coordinator Profile 1}

Hansa*, 24 years (*name changed) is from a Scheduled Caste family. She comes from a family of five members. They live in a basti (slum settlement) for 30 years. Her father works in leather repair and her mother is a domestic worker. Both are daily wage earners. She has done her Graduation in Psychology and Post-graduation in Social Science. She went the 'Learn and Earn' way. Her family said "For how long will you study? If you get further education, it will only help your in laws, how is it of any use to us". They wanted her to work in a Call Centre and earn lots of money and support her family. They could not fathom why she wanted to continue her education. 
Meanwhile, in the classroom and College she felt isolated and abandoned. "The homogeneity with so-called friends felt fake and forced". "Though I did not glorify or capitalize on my hardships, the reality check was too much for my classmates, when I spoke about my family and home”.

In the Disha, Peer Support Group, students of different backgrounds-caste, class, and gender, nationalities came together and interacted on an equal footing. A space was created for discussion and not a debate (debate and discussion have a crucial difference-debate has a 'winner'; discussion is more about laying out views-hence dissensual). It has been about sharing commonalities, dreams, love, attraction and friendships. She got involved in analysis and finding solutions and felt empowered. Leading the group as a Coordinator helped her in resolving her own problems too. She learnt how to look at life dispassionately. Others looked up to her and this helped to build her self-esteem. Her subaltern life experiences became her lode star instead of 'something to hide'.

\subsection{Disha Coordinator Profile 2}

Manoj*, 22 years (name changed) came from a well to do family, was self-assured and articulate. He was interested in academics, theatre and ambitious. His role as Disha Coordinator and interactions with a diverse group made him examine his own lived reality more deeply. He realized that a lot of the other students had financial problems, they lived in crowded spaces and could not afford to entertain or enjoy college life. Some of the sessions on myriad topics such as sexuality, aspirations and love etc. made him realize that he had a lot of autonomy and very little struggle in his life. He also learnt to care for others and connect with those who needed help and moral support. All this was new for him. He realized that but for Disha, their lives would not have intersected at all since college students hang out with PLU (people like us, their own type). This experience was both challenging and rewarding for him. It gave him a sense of proportion and an opportunity to connect with an entire world which was not like his own. It helped him in resolving his personal problems and endowed him with a deep sense of social responsibility. He marveled at the way in which some of his classmates whose life was full of struggle were happy with so little! This motivated him to factor struggle into his life goals. He is now a budding social entrepreneur, who is not merely working for profit.

Both these Coordinators remark very often that the bonds that they forged in Disha are qualitatively different from their other friendships, since this platform allowed people to bare their souls and act real, these bonds are special.

\subsection{Values Arising in the Discussion and from the Profiles}

In both the discussions, the reader must pay attention to the values of plurality and inclusion. The life experiences must be understood in the context of the backgrounds of the students. When compared with each other the impact of caste, 
class, gender, region, nation on lived reality becomes clear and just like the participants, the readers will realize that intersectionality plays a huge role in day-today living and decision-making and is at the core of mental health. Loneliness and isolation are otherwise viewed through a very narrow lens of individualism, but with many contexts, the subtle differences between different categories become clear. It is these differences in turn, which offer entry points and solutions. That there are many freedoms and that it is not absolute is a revelation in the discussion. This is a learning experience for many. The conflicting value systems between the classes of privileged and underprivileged are also comprehended in Disha discussions. Negotiations, strategies that are deployed change according to class and location and though we speak of universal values, multicultural contexts define, challenge and reconstitute values. Disha offers this large canvas to the students.

The three profiles offer the readers a bird's eye view of the processes of validation and interrogation that are deployed in Disha. In every session and every topic that comes up for discussion, both the coordinators as well as participants question the issues and the conflicts that arise because of their own location. Questioning privilege and entitlement, engaging with disadvantage and struggle create a churning of ideas as well as action. Mainstream spaces in Psychology seldom do this. Coordinators from different backgrounds are selected carefully for representing all kinds of voices and to connect the privileged and the excluded and marginalized. Many myths are busted, stereotypes about caste, religion, nationality, race, gender, sexualities are discussed and questioned. Students learn to make an informed choice based on facts and lived experiences that they hear and share rather than forming opinions based on biases and prejudices. The coordinators play a crucial role in this endeavour and empower others and become empowered and inclusive too.

\subsection{The Influences of Culture on This Story}

Pune City is a mini-metro, close to the metropolis Mumbai. Its academic institutions are full of a rich diversity and hence Disha operates within a rich, multicultural context. It caters to both local and global netizen students. This is the exciting and formidable part of running a Speak Out and Peer Support Group for the last 27 years. The understanding of culture here is hence neither homogeneous nor narrow. These young adults, post-millennials are connected to the world through the Internet and social media and are also deeply rooted in the multicultural Indian context. The students from countries as diverse as Mauritius, Uganda, Sri Lanka, Afghanistan, Uzbekistan who are studying with the Indian students and who participate in Disha bring in their own cultural complexities. It is these different strands, with some commonalities and a lot of differences that are constantly challenged, interrogated and unpacked to yield rich insights about psycho-social issues, individual, interpersonal, cross-cultural problems and experiences. In the last few years, the challenges that young adults in India are facing have multiplied. India has the highest suicide 
rates in the world with maximum number of young people on the brink, worse it may soon turn out to be the biggest killer in the country [3]. So apart from dealing with distress, Disha helps to mitigate and ameliorate the mental health of many students on the campus in a non-clinical, non-judgemental, non-hierarchical and non-threatening fashion and this is the raison d'etre of the group.

\subsection{Conclusions}

Disha Peer Support and Speak Out Group offers 'safe space' to students who represent a multilayered and multicontextual diversity. It brings in the complexities of various locations which help to tease out and unpack several psycho-social issues that a typical clinical, counselling or therapeutic setting does not. It challenges the student coordinators as well as the faculty members who are facilitators, since there are no ready-made thumb rules. The peer learning and cross-cultural learning are huge. Disha also helps to shine a light on contextual and intersectionality-related social realities that are key to offering solutions for mental health issues and out of the box practices where students are peer counsellors, with facilitative (and not directive, performative) roles. It draws out principles such as validation and reflexivity and creates an enabling ethos for the lives of the privileged and the excluded to intersect and inform each other's lived reality. In the process, all those who participate in these sessions which revolve around current concerns that change every month and year, go back enriched and armed with life skills. Disha also creates an organic synergy that is beyond the synthetic 'feel good', more humane, earthy, multihued and syncretic. There is a Counselling Cell that is run in the institution, where a lot of self-referral is done as well as referral by staff members. But this is only for critical cases. Primacy is given to Disha, where students themselves are 'healers' and mentors. While faculty members who are facilitators do train Disha coordinators, in the meetings (sessions) their role is more of observers and they make interventions, only when necessary. The transactions in the sessions are multilingual, with translations and hand holding (language specific) which allows all voices to be heard.

Acknowledgements Students have presented the Disha model and learnings at local, national and international conferences. Dr Sadhana Natu has also presented several Disha learnings in national and international conferences. This chapter is based on the collective learnings of many. Students have also written three articles based on their experiential learning and contribution to Disha in local language journals and newspapers.

\subsection{Guides to Further Sources}

https://www.moderncollegegk.org/psychology-dep.php 


\section{References}

1. Natu S. College mental health: the Disha experience, vol. 365-66. Pune: Medico Friends Circle Bulletin; 2015. p. 10-3.

2. Natu S. Youth and Mental Health: Urban, Rural and Fringe Realities, Conference Proceedings. Pune: Siddhivinayak College; 2015. ISBN 9788193144404.

3. Patel V, et al. Suicide mortality in India: a nationally representative survey. Lancet. 2012;379:2343-51.

Open Access This chapter is licensed under the terms of the Creative Commons Attribution 4.0 International License (http://creativecommons.org/licenses/by/4.0/), which permits use, sharing, adaptation, distribution and reproduction in any medium or format, as long as you give appropriate credit to the original author(s) and the source, provide a link to the Creative Commons license and indicate if changes were made.

The images or other third party material in this chapter are included in the chapter's Creative Commons license, unless indicated otherwise in a credit line to the material. If material is not included in the chapter's Creative Commons license and your intended use is not permitted by statutory regulation or exceeds the permitted use, you will need to obtain permission directly from the copyright holder. 